\title{
Sensory attributes of native stingless bee honey (Plebeia molesta Puls, 1869): first approaches to the characterization and preference of local consumers
}

\author{
Melisa G. Geisa ${ }^{1 *}$, M. Cristina Ciappini² ${ }^{2}$ Norma I. Hilgert ${ }^{3}$
}

\begin{abstract}
The sensory quality of a food is related to its characteristics and the consumer's ethno-social and idiosyncratic conditions. In this study, honeys from three different environments in the Chaco region of Córdoba (Argentina) were described qualitatively and quantitatively by specialized evaluators and peasants. Honeys with a wide diversity of sensory attributes were evidenced. The samples from Salinas Coast were characterized by high fluidity, those from Serrano Forest by quantity of crystals, and those from Plain Forest by the greatest persistence of taste. The rural population distinguished honey from Apis mellifera (Linnaeus, 1758), Plebeia nov. sp. (Schwarz, 1938) and Plebeia molesta (Puls, 1869), and described them differentially. At the same time, the peasants used shared descriptors for P. molesta honeys of similar geographical origin, and consumers'preference was $87.5 \%$. We conclude that the sensory components of P. molesta honeys allow their differentiation from the honeys of other melliferous insects and according to the environment of origin. Alsothat the selection of this product as a favorite could be modeled by idiosyncratic factors of the peasants, such as their place of residence and the medicinal properties they attribute to it. Finally, we integrate and discuss the present results with antecedents of this research within the framework of the Socio-ecological Maximization Theory, in an approach to better understand the interaction between local consumers and NSBs.
\end{abstract}

Keywords: Ancestral Foods; Chaco Region; Peasants; Conservation Through Use; Quella.

1 CONICET, INTA AER Cruz del Eje. Av. Eva Perón 451, Córdoba, CP 5282, Argentina.

2 Centro de Investigación y Desarrollo en Tecnología de los Alimentos, Facultad Regional Rosario, Universidad Tecnológica Nacional. Zeballos 1341, Rosario, CP2000, Santa Fe, Argentina.

3 Instituto de Biología Subtropical, Universidad Nacional de Misiones - CONICET. Facultad de Ciencias Forestales, UNaM. Asoc. Civil Centro de Investigaciones del Bosque Atlántico. Bertoni 85, Puerto Iguazú, CP 3370, Misiones, Argentina.

* Corresponding author $\bowtie$. E-mail address: MGG (meligeisa@gmail.com ), MCC (mcciappini@frro.utn.edu.ar),

NIH (normahilgert@yahoo.com.ar) 


\section{SIGNIFICANCE STATEMENT}

This work contributes to the valorization of stingless native bee honeys (NSB) as food with particular characteristics that differentiate them from other honeys. At the same time, it records the peasants' selection of this honey as their favorite. These results provide indispensable information for the characterization and standardization of NSB honeys in Argentina and Latin America. This study is aligned with NSB sustainable use and conservation projects to strengthen the food and medicinal systems of peasant peoples. It provides ethnobiological information analyzed from the new Social-ecological Theory of Maximization wich can turn into an input for sensory and food science for the Argentinean Food Code and for policies and programs of territorial application.

\section{INTRODUCTION}

Honey is a natural sweet substance produced by different bees and wasps, from the nectar of plants, from secretions of their living parts, or from excretions of sucking insects from plants. The insects collect, transform and combine it with their own specific substances, then deposit, dehydrate and store it in the honeycomb to mature (Geisa and Hilgert 2019; Jara 1996; Kamienkowski and Arenas 2012; Ulloa et al. 2010). It is a widely used food in the world and since ancient times nutritional, medicinal and symbolic benefits have been attributed to it in different cultures. To mention some legendary examples, honey was the only sweetener known in Europe until the end of the 15th century, when sugar cane began to be introduced (Carmona 1999); it was also used in mummification processes in Egypt due to its preserving characteristics and antimicrobials, demonstrated in 360 BC (Isidro 2006). In Argentina, honey, was an element of border exchange and trade between native peoples with Spaniards, mulattos and mestizos at the time of the Jesuit settlements in the 17th and 18th centuries (Vitar 2000).

Honeys are differentiated, used and valued according to the insects that produce them (Carvalho et al. 2018; Flores et al. 2018). In the central-northern region of Argentina, the use of wild honeys is deeply rooted in the culture of both native peoples and peasant communities, with a growing interest in recent years (PNUD Argentina 2019). In this context, the bases are being developed to strengthen "meliponicultura" of some species of cultural value following native stingless bees (NSB) breeding and sustainable management practices (Gennari 2019).

NSB honeys have been recently incorporated into the Argentine Food Code to generate quality standards that allow sanitary controls and harvesting, processing and storage protocols (Secretaría de regulación y gestión sanitaria y Secretaría de alimentos y bioeconomía 2019). NSB (Hymenoptera) are represented by 37 species in Argentina (Álvarez et al. 2016). Plebeia molesta (Family Apidae, Tribe Meliponini) occurs in the northwest of Córdoba and is locally known by rural people as quella, among other common names.

Sensory quality can be defined as the appearance, aroma, taste and texture. It has a key influence on how consumers perceive the quality of a product and on consumers' preferences (Green-Petersen 2010). The characteristics of a food are perceived through the human senses and thus generate a sensory description which allows differentiating one product from another (Lawless and Heymann 2010). The sensory quality of honeys depends on several factors such as their botanical origin, prevailing climatic conditions, bee species, and storage conditions (Milojković et al. 2015). Honeys could vary, from light to dark color, liquid or crystallized, more or less sweet, bitter or salty taste as well as aromas such as fruit, floral, vegetable, warm, chemical and animal.

In food, sensory quality results from the interaction between the product and a person (Sancho Valls et al. 1999) since the consumer can perceive sensations related to their ethno-social, psychological and physiological conditions. A sensory evaluation may define the correspondence between those attributes and consumers' expectations (Araújo et al. 2020; Ciappini et al. 2013).

The attributes of NSB honeys have been scarcely studied in Latin America, with a few recent investigations addressing their sensory characterization (Deliza and Vit 2013; Ferreira et al. 2009). In Argentina, the honeys of some NSB species have been studied in terms of their physicochemical and melissopalynological composition but were not subjected to sensory characterization (Maurici et al. 2018).

Plebeia molesta honey is considered an ethnic food among the peasants of the northwest of Córdoba (Argentina), it has been harvested since ancient times and used for medicinal and nutritional purposes according to the knowledge transmitted from generation to generation. It is known as wild honey, pink honey, tree honey, or quella honey and highly valued as a food and medicine source (Geisa and Hilgert 2019). This is a wild product of differential use considered highly effective as a medicinal resource by the peasants of Córdoba (Geisa and Hilgert 2019). In this sense, it is observed that local populations make intentional searches, have their own harvesting practices 
and, due to the scarcity of wild nests, currently handle quella in wooden boxes and develop Meliponiculture to guarantee its availability because of the benefits attributed to it. Besides, Plebeia molesta produces an average of $250 \mathrm{ml}$ of honey per nest each summer season, being a limited resource. In the same way, it was recorded that peasants conserve honey in their homes for months and years to be used in the treatment of health conditions, and they transmit particular ways of employment according to each ailment (Geisa 2020) from generation to generation.

The Social-ecological Theory of Maximization (Albuquerque et al. 2019) mainly postulates that over time, human beings build social-ecological systems to favor survival in different environments. In particular, the conceptual model of environmental maximization proposes how human populations select a biota and use it over time in search for strategies tending to reduce costs and maximize benefits. The antecedents briefly mentioned in this research (Geisa 2020; Geisa and Hilgert 2019), agree with some basic concepts of this innovative theory elaborated from Ethnobiology. That is why it seems appropriate to explore our study within this theoretical framework, integrating the new information obtained.

When considering the importance of quella honey in the local culture, we propose that the current interest in generating conditions and improving skills for its breeding and for producing its honey, highlights a conscious strategy to maximize the availability of a resource selected by the level of cultural satisfactors its possession implies. This interest was locally developed by the growing perception of the decrease in wild nests, the increase in clearings and changes in land use in the region in recent decades. Instead of replacing quella honey with Apis mellifera honey, commonly produced in the region (Garzón and Young 2016), the local society has generated meliponiculture as an adaptive response to changes to preserve a resource of traditional use. Meniponiculture being an activity supported in recent years by different government and academic agencies that promote the conservation and sustainable use of these bees and non-wood forest products of cultural, nutritional and medicinal importance (Geisa 2020).

In light of these theoretical axes, we propose as a working hypothesis that according to their sensory attributes the honeys of Plebeia molesta are distinctive with respect to the honeys produced by other bees. For this reason, we hope to find that rural inhabitants describe quella honey differently from honeys of other insects and distinguish them from each other. In turn, we consider that idiosyncratic consumer factors (knowledge, beliefs, habits, behaviors, etc.) influence the process of classification and selection of a food. Taking into account that quella honeys are valuable for these peasant communities as a medicinal resourceof nutritional and symbolic importance (Geisa and Hilgert 2019), and that the preference of a food is not only related to the sensation of taste mediated by its organoleptic characteristics (Sacho Valls et al. 1999), we hope to find that rural inhabitants choose $P$. molesta honeys as their favorite.The first objective of this work was to identify the sensory characteristics of Plebeia molesta honeys from three native forest environments in the northwest of Córdoba, applying an evaluation carried out by a group of researchers trained in sensory analysis. Second, we analyzed the descriptions assigned to the honeys of P. molesta, Apis mellifera and P. nov. sp. from the perception of local residents, based on their knowledge and personal experience; if they were distinguished from each other and which wered the honeys preferred by the peasants. A final objective that we propose is to present an approach to the analysis of the relationship between the local peasants, the native stingless bees and their honey within the framework of the Social-ecological Theory of Maximization.

The results of this work provide novel information, may contribute to the assessment of NSB honeys and on their characterization. Through the use of two different methodologies, the perspective of experts in food characterization and that of local consumers is obtained.

\section{MATERIAL AND METHODS}

\section{Study area}

The northwest of Córdoba province is located within the Dry Chaco phytogeographic region of Argentina (Morello et al. 2012). The study area encommpasses three natural environments along a decreasing altitudinal gradient, with different plant communities, climate, soils and relief: Serrano Forest, Plain Forest or Western Chaco, and Salinas Coast. Plebeia molesta occurs in the three environments. The study was conducted in rural localities with well-preserved native vegetation in the departments of Cruz del Eje, Minas, Pocho, San Javier, and Ischilín (Figure 1).

The inhabitants of northwestern Córdoba were characterized as criollos or peasants: people of mixed Spanish-aboriginal origins, descendants of Comechingones and Sanavirones indigenous peoples and immigrants who arrived in the region during the Spanish colonization (Grimaldi and Trillo 2018). The participants of this study harvest wild nests and some keep P. molesta for honey production for self-consumption and commercialization. They live in rural towns with different degrees of urbanization and provision of basic services. In one of the towns (San Marcos Sierras), 

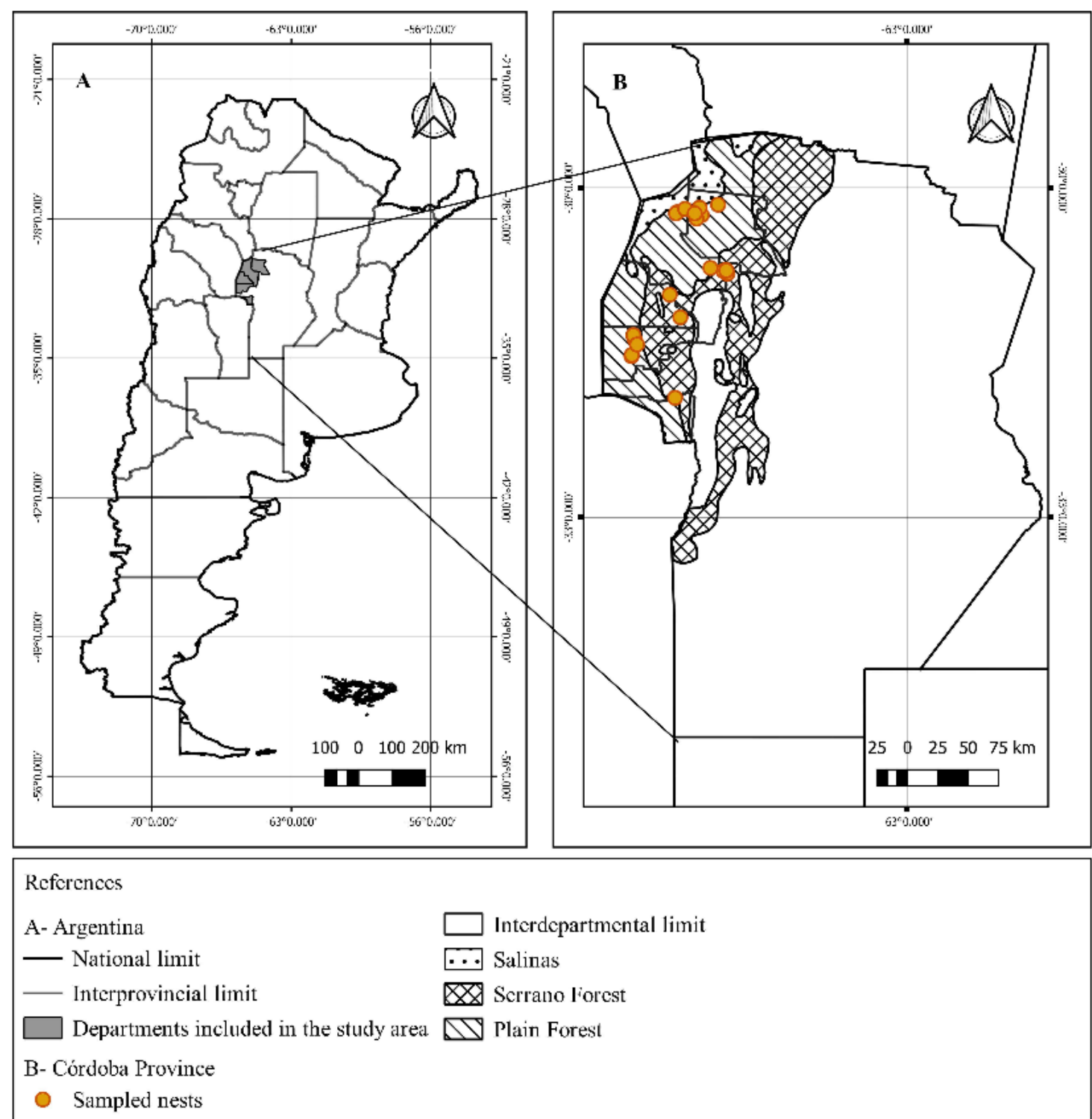

Figure 1. Córdoba province in Argentina (A) and sampled nests in the study area (B).

three native people communities are recognized by the INAI (Instituto Nacional de Asuntos Indígenas) and have legal status.

\section{Methodology}

\section{Sampling of honeys}

Regional residents with a link with $P$. molesta honey were selected using the "Snowball technique" (Bernard 2000). With its accompaniment, we identified and recorded 54 nests of Plebeia molesta during the 2016-2017 summer season. 27 nests were opened from dry trunks, branches and rustic boxes in residents' piece of land (Figure 2).

Honey samples were gathered following the "Pro- tocol for collecting samples of native stingless bee (NSB) products and specimens" (INTA 2016), then transported to the laboratory in a portable $12 \mathrm{v}$ refrigerator and kept at $4^{\circ} \mathrm{C}$ until honey analysis. The amount of honey produced in each nest was very variable $\left(10 \mathrm{~cm}^{3}\right.$ to $\left.110 \mathrm{~cm}^{3}\right)$; therefore, honey samples were mixed taking into account the overlap of the estimated flight range of Plebeia molesta (Greenleaf et al. 2007) and the proximity between nests. Ten (10) samples of honeys (minimum $100 \mathrm{~cm}^{3}$ ) were obtained (four from the Plain Forest, three from the Serrano Forest and three from Salinas Coasts) for the sensory evaluation by specialists. For sensory analysis by consumers, honey samples $\left(30 \mathrm{~cm}^{3}\right)$ were not mixed and included samples from two of the three environments 


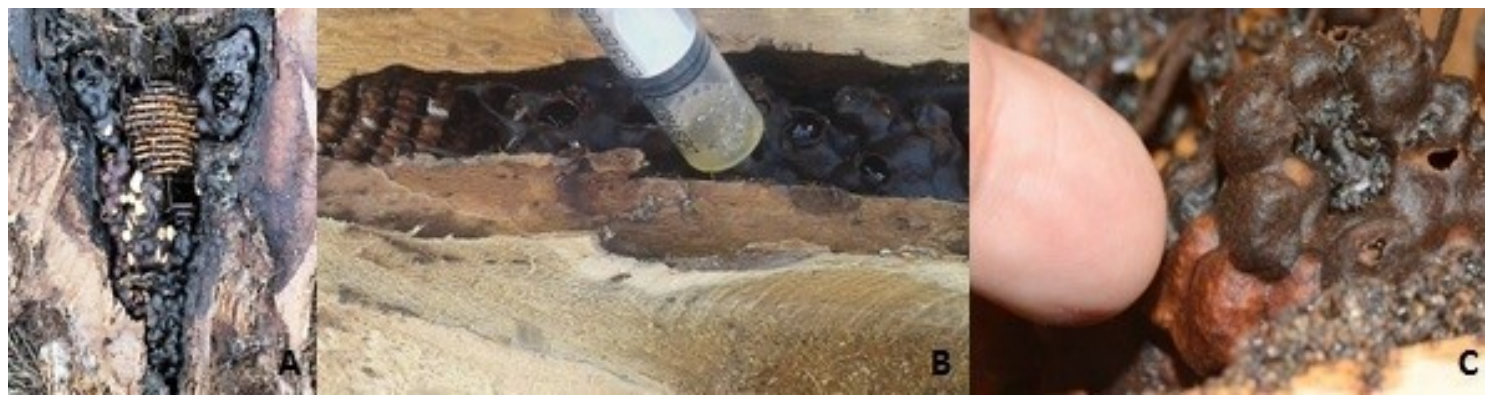

Figure 2. Natural nest of Plebeia molesta (A). Honey harvest (B). Honey pots (size compared to that of the finger of an adult person) (C).

(Salinas Coast was excluded due to the low amount of honey collected).

\section{Sensory evaluation by expert panel}

The sensory analysis was performed in the CIDTA - FRRo Laboratory of the Universidad Tecnológica Nacional, using the Descriptive Quantitative Analysis methodology. Sample presentation, work methodology and evaluation form followed Ciappini (2013). A panel of seven selected and trained assessors (ISO 8586: 2012) identified the sensory stimuli, based on previously learned standards.

The Sensory evaluation panel consisted of 7 assessors, both male and female, in the age group of 23-56. They were selected from a recruited group of thirty-six people using different screening tests: a basic taste test, an odour recognition test, the Ishihara test for colour, two intensity ranking tests (acid taste and bitter taste), a texture description test and a sequential test for difference. Assessors were trained in odour and flavour lexicon with references and natural products. Training involved fifteen sessions.

Testing was performed in individual booths. A twenty-gram unique sample of honey was served at room temperature $\left(23 \pm 5^{\mathrm{o}} \mathrm{C}\right)$ in a wineglass labelled with a three-digit code. Three successive phases were considered: visual, olfactory and gustatory. Persistence of taste was evaluated after swallowing the sample. Water and unsalted bread were used as palate cleansers between samples. Perceived sensations were recorded on individual sheets at first. Each term was evaluated using a scale ranging from zero (absence) to seven (very intense), allowing a quantitative measurement (ISO 4121: 2006). The assessors were asked to mark the perceived intensity of the attribute by drawing a vertical line that intersected the visual analogical scale. Then the assessors met together and agreed on the values obtained individually following the Consensus Method (ISO 6564: 1985). This procedure was repeted whit each honey sample.

\section{Perception of local consumers}

The sensory evaluation was carried out in a suitable room of the Cruz del Eje Cultural Center and involved 24 residents of the region, 10 men and 14 women between the ages of 25 and 70 , who voluntarily attended and gave their prior informed consent as participants. It was used the "Check All That Apply method" (Belusso et al. 2016) from a set of five honeys placed in $30 \mathrm{~cm}^{3}$ glass containers. The tasting methodology was explained to them: they should observe, smell, and taste the honeys with a sterile stirring rod; then, they had to fill the form, selecting and adding the terms they considered suitable to describe each sample (Additional file 1). In all cases, the honey samples were identified with random three-digit numbers, so that the entomological and geographic origin of each sample was unknown to the consumer.

This method was performed three successive times. The first time involved five honeys: three samples of Plebeia molesta (two from the Plain Forest and one from Serrano Forest), one of Apis mellifera and one of Plebeia nov. sp. (commonly named mansita); the next two times involved sets composed of $P$. molesta honeys. After this procedure, participants indicated which sample they liked best and which samples corresponded to each melliferous insect. Peasants mentioned that Plebeia molesta honeys are similar, regardless of the environment of origin, and may change occasionally according to the tree in which the nest is housed, although such change is very rare (Geisa 2020).

\section{Statistical analysis}

Only consumers, in this case peasants, responded for preferences, trained assessors do not because, as a result of their training, their preferences are biased and they are not considered as representative of the local peasant community that is our population of interest in this study.

To test our hypothesis, the following Pearson Chisquare tests were performed to evaluate the indepen- 
dence between the analyzed variables, using the Infostat program (Di Rienzo et al. 2008):

a - According to our hypothesis, we hope to find that the peasants differentiate the honeys of quella based on the sensory attributes, with respect to A. mellifera and Plebeia nov. sp. Therefore, we carried out a Chi-square test to observe if the description of the honey (color, smell, taste) and the classification made by the peasants are independent from the insect that produces it.

Furthermore, the associations between sensory descriptions and the geographical origin of Plebeia molesta honeys were examined using a principal component analysis (PCA) and the results are presented in a scatter biplot (Balzarini et al. 2008). This exploratory analysis is related to our interest in knowing whether the peasants assign different sensory attributes to the quella honeys of different geographical origin.

b - Secondly, to evaluate whether the peasants prefer quella honeys as we initially suggested, we performed a Chi-square to observe if the honey selected by the peasants as their favorite is associated with the species of bee that produces it.

Then, considering that the place of residence is one of the idiosyncratic factors that could influence the peasants'preference process, we explored, by means of a Principal Component Analysis (PCA), the honeys selected by the participants as favorites, the participants' place of residence and the honey geographical origin.

\section{RESULTS}

\section{Sensory description of honeys by trained evaluators}

The sensory evaluation made by trained assessors indicated that $P$. molesta honeys are not uniform and might differ according to the environment of origin. The mean values of the sensory characteristics are shown in Figure 3. The honeys showed differences among the three geographical environments of origin. The honeys from Salinas Coast showed high fluidity $(\bar{X}=7)$; those from Serrano Forest stood out for their quantity of crystals $(\bar{X}=6)$, were less sweet and had more intense odors; and Plain Forest honeys were distinguished by their taste, persistence and the high variability of sensory characteristics with respect to the other.

According to the qualitative description, aroma and odor were the attributes with the greatest differences between environments. Salinas Coast honeys were characterized by a warm and fruity aroma; those from Serrano Forest presented animal, vegetable, chemical, warm or fermented fruit aromas; and Plain Forest honeys had a warm aroma of vanilla, fruit, or vegetable wood. Honeys from the three environments had acid taste. Except for a sample from Plain Forest, which was dark, the color of the remaining honeys varied from light to dark amber. Qualitative characterizations of each honey according to the visual, olfactory and flavor examination are described in the complementary material (Additional file 2).

\section{Description and classification of honeys according to consumer perception}

The sensory evaluation that involved the peasants aroused interest and surprise, since they perceived $P$. molesta honeys of different colors, taste, aromas and textures.

According to the Chi-square tests carried out, the description made by the peasants and the distinction of honeys according to their sensory characteristics (color, smell and flavor), are dependent on the bees that produce them (quella, $P$ nov. sp. and A. mellifera), such as is observed in Table 1 . Therefore, our results support the proposed hypothesis, observing that the sensory differentiation that the peasants make is related to the entomological origin of the same.

The descriptors highlighted as attributes to recognize A. mellifera were flavor and consistency; and for Plebeia nov. sp., descriptors distinctive included honey acidity, unknown taste and smell with respect to the wild honeys of P. molesta of "known" characteristics.

The sensory descriptions assigned to the honeys of each species are shown in Figure 4. The participants mentioned medium and dark color, variable hue and smell, very sweet taste (53\%), acid and somewhat salty the honey of $P$. molesta. The honey of $P$. nov. sp. It was mostly described as having a medium intensity color, "reddish hue" and "greenish", intense smell (80\%), and acid taste (83\%). A. mellifera honey was characterized more frequently by its light color $(80 \%)$, mild odor $(75 \%)$, yellowish tone, and very sweet taste $(100 \%)$.

Later, the results of PCA on the perception of sensory characteristics of $P$. molesta honeys (Figure 5) indicate that peasants' descriptions generated honey sensory profiles that differed with geographical origin. PC1 and PC2 accounted for $60 \%$ of total variability. The profile of Serrano Forest honeys is separated from that of Plain Forest honeys by $39.4 \%$ along PC 1 .

In this activity, it was observed that the honeys were characterized in different ways, with some attributes being common to honeys from the same environment. The honeys from Serrano Forest were described using the following attributes: dark color, medium and intense aroma, acid, bitter and some- 


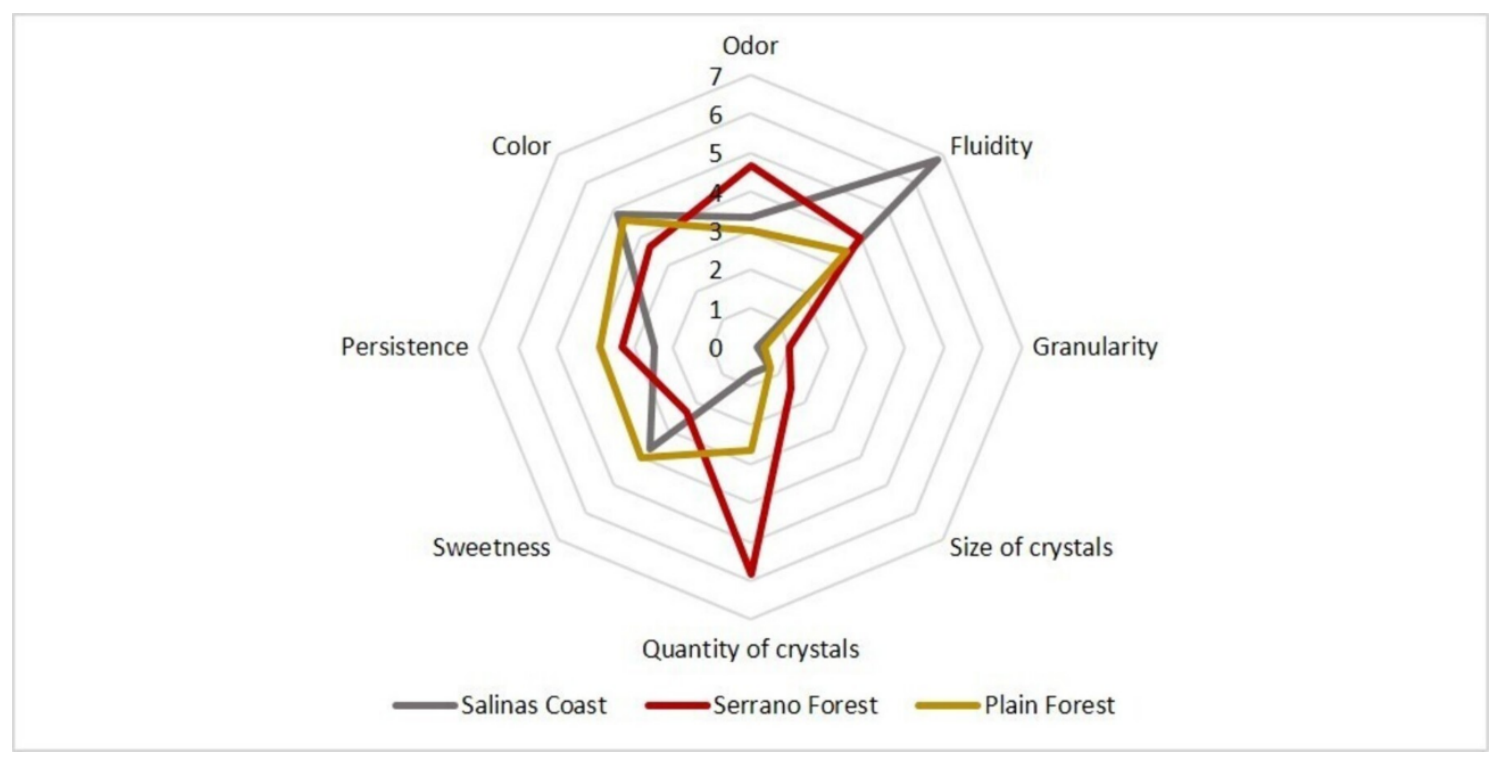

Figure 3. Average intensity of sensory stimuli in honeys of Plebeia molesta from three different environments of northwestern Córdoba, within a range between 0 (absence) and 7 (very intense).

Table 1. Estimated values of the Chi-square statistic between the description of the sensory attributes and the differentiation of honeys, and their entomological origin.

\begin{tabular}{|c|c|c|c|c|c|c|c|c|}
\hline \multirow[t]{2}{*}{ Parameters } & \multicolumn{3}{|c|}{ Chi-square Pearson } & \multicolumn{3}{|c|}{ Chi-square MV-G2 } & \multirow{2}{*}{$\begin{array}{l}\text { Conting. } \\
\text { coeff. } \\
\text { Cramer }\end{array}$} & \multirow{2}{*}{$\begin{array}{l}\text { Conting. } \\
\text { coeff. } \\
\text { Pearson }\end{array}$} \\
\hline & Value & $\mathrm{df}$ & $\mathrm{p}$ & Value & df & $\mathrm{p}$ & & \\
\hline $\begin{array}{l}\text { Sensory attributes assigned } \\
\text { for the description of honeys }\end{array}$ & 183.09 & 112 & $<0.0001$ & 176.85 & 112 & 0.0001 & 0.75 & 0.79 \\
\hline $\begin{array}{l}\text { Distinction of honeys according } \\
\text { to their entomological origin }\end{array}$ & 225.47 & 188 & 0.0321 & 210.45 & 188 & 0.1254 & 0.78 & 0.81 \\
\hline
\end{tabular}

thing salty taste. As for the Plain Forest honeys, the descriptors common to all the samples from this environment were medium color, mild odor and very sweet taste.

\section{Honeys preferred by peasants}

Different $P$. molesta honeys were selected as favorites in $87.5 \%$ of the cases. According to the Chisquare statistic (Table 2), it was observed that the honeys chosen as favorites are associated with the bee that produces them $(p=0.028)$.

Two honeys from Plebeia molesta from Plain Forest were selected with $32 \%$ citations each, and to a lesser extent honeys from P. molesta from Bosque Serrano $(23.5 \%)$. A. mellifera honey was preferred by $14 \%$ of the peasants.

Figure 6 shows the results of the PCA for honey preference of the 24 participants relative to their residence environments. PC1 and PC2 accounted for $77.3 \%$ of the total variability. The consumer prefer- ence for a given honey was associated with their site of residence, and opposed to the geographical origin of honey in $43.1 \%$ (PC 1). In other words, this cultural factor would be influencing the process of selecting a honey by the peasants.

\section{DISCUSSION}

In this work we present the first sensory descriptions for P. molesta honeys. Then, according to tour results, we confirm that rural inhabitants identify quella honey from honeys produced by other bees based on their sensory attributes, describe them in different ways and, in turn, select them as their favorites, which supports our initial working hypothesis.

The analyzes by trained evaluators show that $P$. molesta honeys are not uniform in their sensory characteristics and might differ according to the environment of origin. These varieties may be related to the different types of nectars bees use to produce 


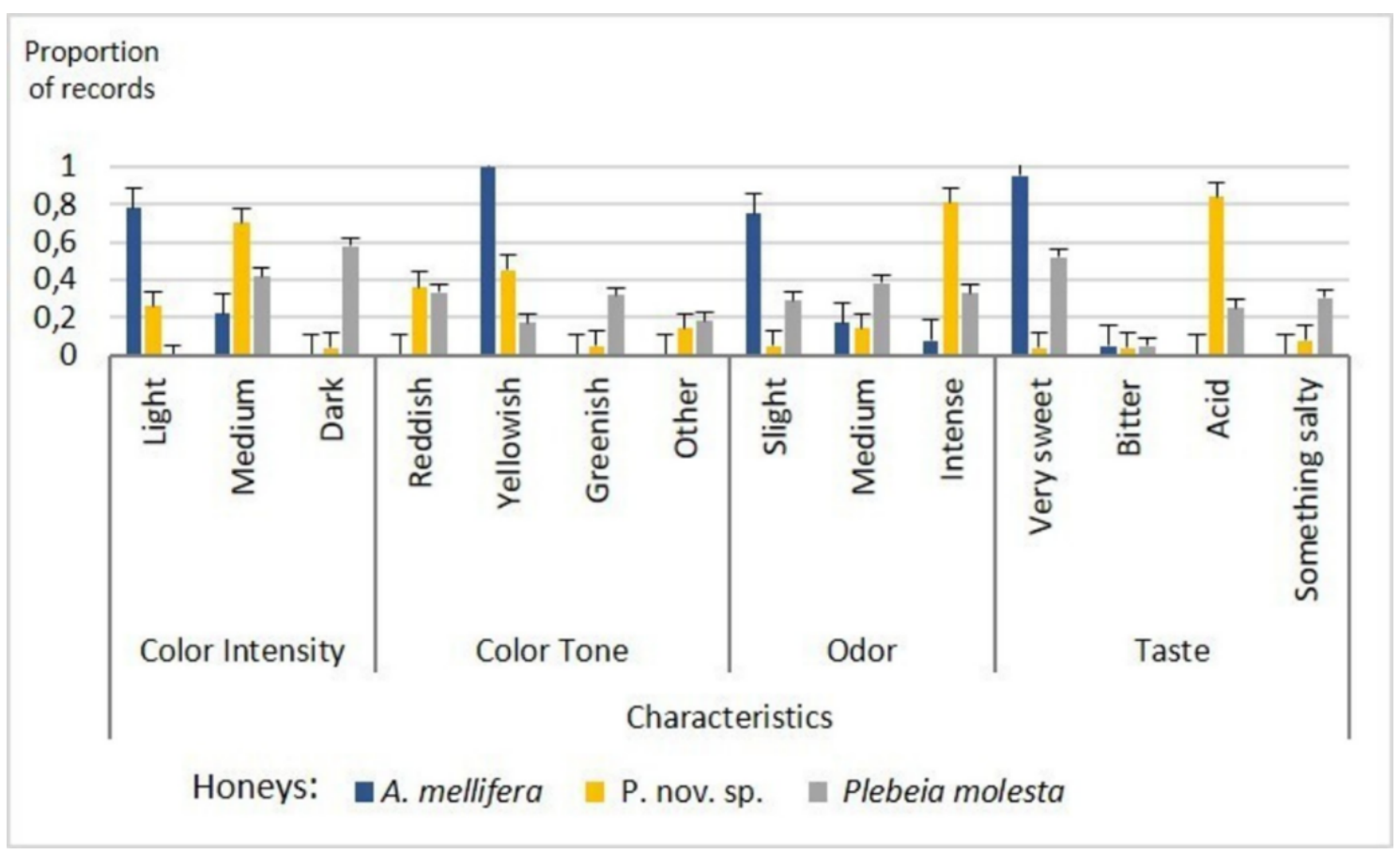

Figure 4. Description of honeys by non-expert consumers.

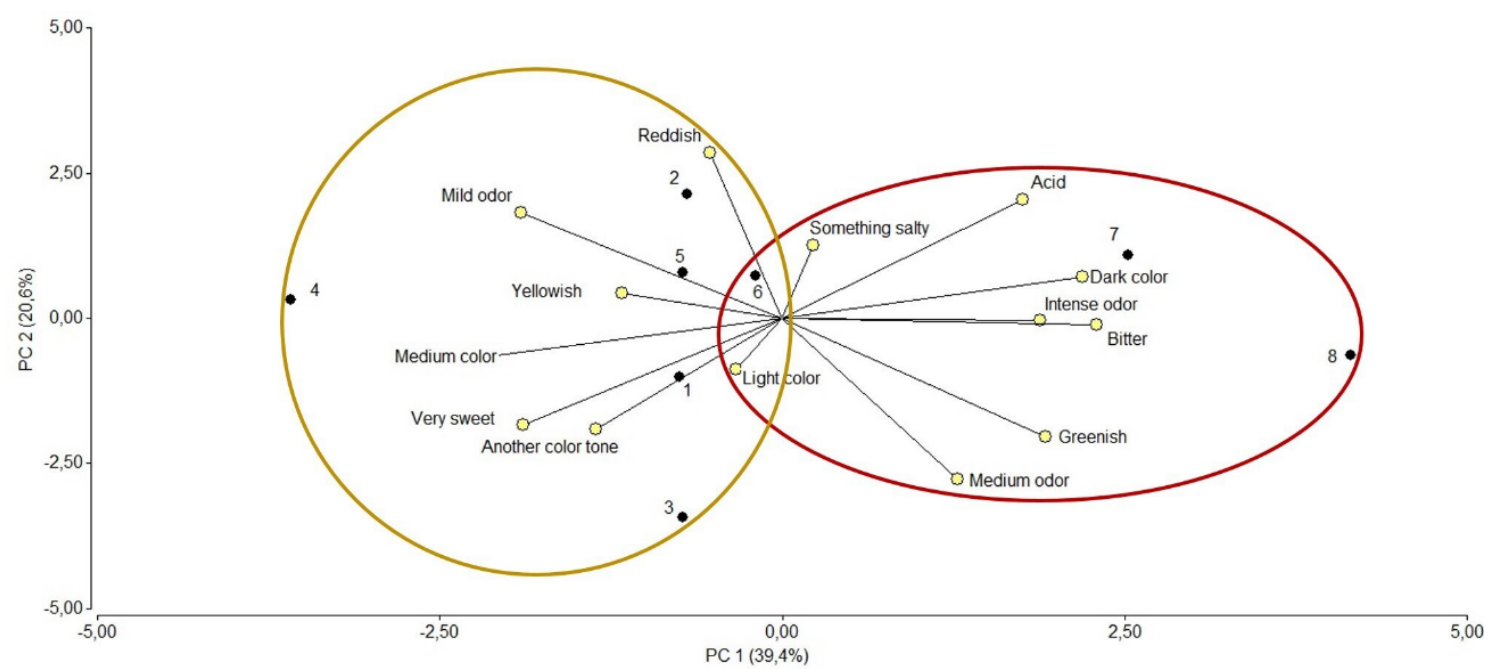

Figure 5. Profiles of honeys from Plain Forest (yellow) and Serrano Forest (red) according to the descriptions made by local consumers.

Table 2. Chi-square statistic estimated for the preference in relation to the entomological origin of the honeys.

\begin{tabular}{llllllllll}
\hline \hline Parameters & Chi-square Pearson & Chi-square MV-G2 & $\begin{array}{l}\text { Conting. } \\
\text { coeff. } \\
\text { Cramer }\end{array}$ & $\begin{array}{l}\text { Conting. } \\
\text { coeff. } \\
\text { Pearson }\end{array}$ \\
& Value & df & $\mathrm{p}$ & Value & df & $\mathrm{p}$ & & \\
\hline $\begin{array}{l}\text { Honey select } \\
\text { as favorite }\end{array}$ & 20 & 6 & 0.0028 & 16.91 & 6 & 0.0096 & 0.71 & 0.71 \\
\hline \hline
\end{tabular}

their honeys, their flight range, and bees physiology and foraging habits, as indicated for A. mellifera hon- eys (Montenegro et al. 2008) and other NSB species

(Vit et al. 2011). Therefore, studies on sensory char- 


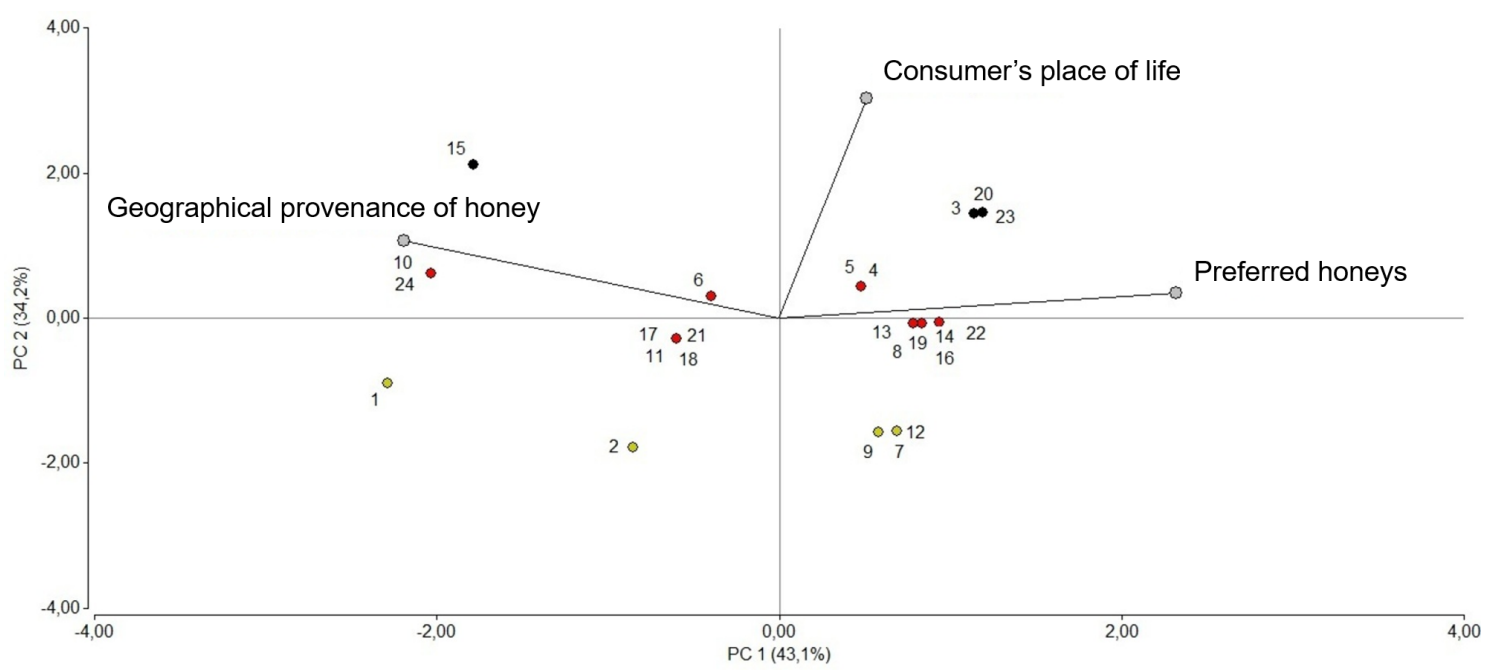

Figure 6. Preferred honey in relation to the consumer's place of residence and honey geographical origin. Peasants from Serrano Forest are indicated in red, those from the Plain Forest are indicated in yellow, and those from other environments in black.

acterization of $P$. molesta honeys should be further extended and complemented with palynological analyzes in order to associate their attributes with their botanical origin.

Similarly, peasants described $P$. molesta honeys using attributes common to honeys of the same geographical origin and recognizing particular characteristics in honeys from different environments. This was also observed in the responses of consumers on the distinction between $A$. mellifera and $P$. nov. sp. honeys, with respect to the wild honeys of $P$. molesta; arguing that they recognized "known" and "unknown" flavors. The classification systems used by rural groups to describe and recognize NSB honeys are reported for other regions of the country and Latin America (Ferreira et al. 2009; Zamudio and Hilgert 2017), and as observed in this study, are part of the "cultural domain" (Albuquerque et al. 2019) structured around the perceptions, knowledge and practices of the peasants in relation to this resource.

The sensory perception of a food item is related to the consumers' ethnic-social, psychological and physiological conditions which determine their level of comfort and pleasure. Consumers not only taste what they eat, but also value what food means to them in terms of tradition, feelings and values (Shack 1995). This phenomenon responds to a pattern acquired during childhood which will make people select and reject food throughout life.

In this work, the preferred honeys, were those of P. molesta; and in the analyzes carried out we observed that cultural factors such as the consumer's place of residence could be intervening with the preference process of this food. Indeed, in some cases the consumer's place of residence coincided with the honey collection site that they selected as their favorite. In addition, the differential use of this honey in the traditional medicine of these communities consideres it highly effective in the treatment of conditions of various body systems in people of all ages (from newborn children to older adults) (Geisa and Hilgert 2019). These observations suggest the importance of the cultural component in defining feelings of acceptance of a food item, linked to subjective factors or impressions that influence the selection of the "most delicious" or "the best honey". Savoring a known food can reflect the power of everyday experiences to evoke memories on which identities are formed, as well as local knowledge, which makes people prefer or reject food throughout life (Shack 1995; Sutton 2001). Similarly, a higher level of acceptance of NSB honey by people from different countries in Latin America was demonstrated, compared to consumers in European countries where this honey is alien to the place they inhabit (Deliza and Vit 2013). In this sense, we consider it interesting to deepen studies that address other idiosyncratic factors that may be modeling the process of description, classification and selection of this resource, in order to identify which of them have the greatest influence on the relationship "food / honey-consumer / peasant".

The place of residence, together with the food and medicinal uses observed in Geisa and Hilgert (2019), are idiosyncratic factors that could be influencing the selection of this currently scarce resource. At the same time, in a context where there are different alternatives the preference of a food decisively influences its obtention and consumption (Maya and Alemán 1993). Therefore, the selection of $P$. molesta honeys as favorites can be one of the strongest modelers of 
the strategies that peasants organize and structure to meet their consumer demand.

According to the farmers, the costs of finding wild nests are increasingly high and alternatively, they are beginning to develop meliponiculture to ensure this resource used to strengthen health (Geisa 2020; Geisa and Hilgert 2019). We consider this action as a strategy that they develop in order to maintain the survival of the communities, seeking the "maximum performance" of this resource, defined as the best possible result according to the social-ecological theory of maximization (Albuquerque et al. 2019). From this perspective, Meliponiculture can be considered the "non-random experimentation" that rural populations are currently deploying in the territory to incorporate the management and production of quella honey in their diversified production systems.

In the northwest of Córdoba, the most accessible honey in terms of quantity is that of Apis mellifera, which has been produced in the territory for more than 100 years, mainly by small and medium peasant beekeepers (Mesa Apícola del Noroeste de Córdoba 2016). However, the demand for quella honey has not been replaced by that of $A$. mellifera honey, on the contrary, we observe that the value of $P$. molesta and its honey has been increasing in recent years. In this sense, in Geisa and Hilgert (2019) the contrasted attitudes that peasants recognize according to their previous and present perceptions are mentioned: "Decades ago, quella was considered such an annoying insect during work in the forest, that the nests were withdrawn only with the purpose of reducing its abundance in the workplace. Currently, this perception has changed towards a high interest in having hives in the house, learning about the management of colonies and being able to harvest honey without damaging the nest; getting to recognize sites nearby with mature forest that can provide mother nests". In this way, we can observe that different cognitive and behavioral mechanisms of peasants in relation to $P$. molesta have changed over time. At present they prioritize the development of meliponiculture and the management and conservation for obtaining and maximizing the resource as a strategy, in contrast to the wild exploitation they have practiced since ancient times. They perceive this previous practice as counterproductive since, the harvested nest is lost, reducing the reproduction of colonies in the forest, and consequently decreasing the chances of obtaining this honey which has medicinal properties and is preferred over the honeys of other melliferous insects. According to the study antecedents and the results found, we consider that the interaction of peasants with Plebeia molesta and their honey can exemplify the Model of Maximum Environmental Performance (Albuquerque et al. 2019).

On the other hand, the quality standards estab- lished by the legislation for honeys of the genus Apis do not apply to the evaluation of the quality of NSB honeys (Secretaría de Regulación y Gestión Sanitaria y Secretaría de Alimentos y Bioeconomía 2019) as reported for other Latin American countries (Vit 2008). Acid taste was recognized in the honeys of the two evaluated NSBs but not in A. mellifera, as observed in other regions of Latin America (Ferreira et al. 2009; Vit et al. 2011). Thus, acid taste could be a distinctive descriptor of NSB honey. In both types of evaluations (with experts and local consumers), a terminology exclusive for NSB honey descriptors could be used in order to classify these honeys and describe the universe of perceived sensations, as defined in other Latin American countries (Vit 2008). In agreement with Ciappini (2013), our findings suggest that the application of a sensory analysis to a given product requires adapting the general methodology of this discipline to that particular product.

This work may contribute to the conservation of NSBs through the valuation of their honeys, culture of peasants from northwest of Córdoba and the conservation of native forests.

\section{CONCLUSION}

The sensory attributes of $P$. molesta esta honeys allow them to be recognized and described as distinctive products from the honeys of other melliferous insects. Idiosyncratic factors of rural inhabitants could be modeling the selection of this resource as their favorite.

The preference of this food, its differential uses and the scarcity of wild nests recognized by the peasants are part of the elements that drive the management processes of NSB in order to guarantee the availability and access to their honeys of nutritional and medicinal value.

The results observed in this work and its antecedents can exemplify basic concepts and definitions of the Social-ecological Theory of Maximization and the Model of Maximum Environmental Performance proposed from Ethnobiology, in an attempt to approach the understanding of the interaction between peasants and their environment. Peasants choose P. molesta honey as part of their socio-ecological systems, they look for it intentionally and they incorporate it into their nutrition and health strategies, and therefore into their survival mechanisms. In addition to this, they select it as a favorite food and are currently seeking to meet the demand they make for this resource through meliponiculture.

The results of the laboratory analyses showed that the honeys of a given environment share attributes that make them particular products. 
The sensory response of rural consumers reflects a subjective process influenced by culture in the perception and preference for $P$. molesta honeys. In addition, the sensory component of NSB honeys has been sufficient to discriminate them from Apis mellifera honeys.

This first approach to the sensory evaluation of Plebeia molesta honeys aims to contribute to the appraisal of the NSBs from Córdoba, recognizing their characteristics and their status as a favorite food for local consumers. In order to continue analyzing the quality of quella honey, the present results must be deepened and complemented with palynological, physical-chemical and microbiological studies.

\section{ACKNOWLEDGEMENT}

The authors thank the technical collaboration of Dr. Laura Gurini and Ing. Carolina López (INTA Delta). To the Park rangers Eduardo Martínez and Nicolás Maldonado for technical assistance in field sampling. To Jorgelina Brasca and Haydée Gonzalez for her contribution in language revision. To Dra. Monika Kujawska for her revision and contributions. To Ing. Franco Brunelli for his assistance in adapting colors.

This work was supported by CONICET (Type 1 Doctoral Scholarship to M. G. Geisa), the Secretaría de Políticas Universitarias (SPU) of the Ministerio de Educación de la Nación Argentina (Proyect PCESU9UNCOR1110), Proyect PROCODAS 2015 (N 44), Ministerio de Ciencia, Tecnología e Innovación Productiva, and P- Unidades Ejecutoras CONICET, IBS, UNaM-CONICET.

\section{DATA AVAILABILITY}

All data and materials are shared in this article.

\section{CONFLICT OF INTEREST}

The authors have no conflicts of interest to declare.

\section{CONTRIBUTION STATEMENT}

All authors participated materially in the research and preparation of the article. The figures were made by Geisa M. G.

\section{REFERENCES}

Albuquerque UP, de Medeiros PM, Júnior WSF, da Silva TC, da Silva RRV, Gonçalves-Souza T (2019)
Social-Ecological Theory of Maximization: Basic Concepts and Two Initial Models. Biological Theory 14:73-85.

Álvarez LJ, Rasmussen C, Abrahamovich AH (2016) Nueva especie de Plebeia Schwarz, clave para las especies argentinas de Plebeia y comentarios sobre Plectoplebeia en la Argentina (Hymenoptera: Meliponini). Rev. Mus. Argent. Cienc. Nat. 18:65-74.

Araújo D, Ruiz Pérez-Cacho P, Serrano S, DiosPalomares R, Galán-Soldevilla H (2020) Sensory Profile and Physico-Chemical Properties of Artisanal Honey from Zulia, Venezuela. Foods doi: $10.3390 /$ foods9030339.

Balzarini M, Bruno C, Córdoba M, Teich I (2015) Herramientas en el análisis estadístico multivariado. Escuela Virtual Internacional CAVILA, Facultad de Ciencias Agropecuarias, Universidad Nacional de Córdoba, Córdoba, Argentina.

Belusso AC, Nogueira BA, Breda LS, MittererDaltoé ML (2016) Check all that apply (CATA) as an instrument for the development of fish products. Food Science and Technology doi: 10.1590/1678-457X.0026.

Bernard HR (2000) Social Research Methods. Qualitative and Quantitative Approaches. Sage Publications, Thousand Oaks, Londres, Nueva Delhi.

Carmona Ruiz MA (1999) La apicultura sevillana a fines de la edad Media. Estudios Agrosociales y Pesqueros 185:131-154.

Carvalho RMA, Feitosa Martins C, Nóbrega Alves RR, Chaves Alves ÂG (2018) Do emotions influence the motivations and preferences of keepers of stingless bees? Journal of Ethnobiology and Ethnomedicine doi: 10.1186/s13002-018-0246-3.

Ciappini MC (2013) Sensory analysis applied to bee honey. In: Calviño A. (ed) Recent Contributions to Sensory Analysis of Foods. Research Signpost, Kerala, India, pp. 21-32.

Ciappini MC, Di Vito MV, Gatti MB, Calviño AM (2013) Development of a Quantitative Descriptive Sensory Honey Analysis: Application to Eucalyptus and Clover Honeys. Advance Journal of Food Science and Technology doi: 10.19026/ajfst.5.3169.

Deliza R, Vit P (2013) Sensory Evaluation of Stingless Bee Pot-Honey Chapter 24. In: Vit P, Pedro SRM, Roubik D (Eds.). Pot-Honey: A legacy of stingless bees Springer Science \& Business Media, New York, EEUU, pp. 349-361. 
de Maya SR, Alemán JLM (1993) Las preferencias del consumidor: estudio de su composición a través del análisis conjunto. Estudios sobre consumo 28:27-43.

Di Rienzo JA, Casanoves F, Balzarini MG, Gonzalez L, Tablada M, Robledo CW (2008) InfoStat versión 2008. Grupo InfoStat, FCA, Universidad Nacional de Córdoba, Argentina.

Ferreira EL, Lencioni C, Benassi MT, Barth MO, Bastos DHM (2009) Descriptive Sensory Analysis and Acceptance of Stingless Bee Honey. Food Sci Tech Int. doi: 10.1177/1082013209341136.

Flores FF, Hilgert NI, Lupo L (2018) Melliferous insects and the uses assigned to their products in the northern Yungas of Salta, Argentina. Journal of Ethnobiology and Ethnomedicine doi: 10.1186/s13002-018-0222-y.

Garzón JM, Young M (2016) La actividad apícola en Córdoba. Aspectos básicos y potencial productivo. IERAL - Ministerio de Agricultura y Ganadería de Córdoba, Córdoba, Argentina.

Geisa MG (2020) Análisis de los usos locales y la calidad de mieles de abejas nativas sin aguijón del noroeste de Córdoba, Argentina. PhD Thesis. IDACOR, Universidad Nacional de Córdoba - CONICET, Córdoba, Argentina.

Geisa MG, Hilgert NI (2019) The honey of Plebeia molesta and other melliferous insects in the peasant culture of the Northwest of Córdoba, Argentina. Ethnobiology and Conservation doi: 10.15451/ec2019-08-8.11-1-18.

Gennari GP (2019) Manejo racional de las abejas nativas sin aguijón - ANSA. Ediciones INTA, Famaillá, Tucumán, Argentina.

Green-Petersen DMB (2010) Sensory Quality of Seafood - in the Chain from Catch to Consumption PhD Thesis. Copenhagen, Denmark: University of Denmark.

Greenleaf SS, Williams NM, Winfree R, Kremen C (2007) Bee foraging ranges and their relationship to body size. Oecologia doi: 10.1007/s00442007-0752-9.

Grimaldi PA, Trillo C (2018) Prácticas y usos tradicionales de "cerco" y "monte" por los criollos de San Marcos Sierras (Córdoba, Argentina). Bonplandia doi: 10.30972/bon.2712986.

INTA (2016) Protocolo para la toma de muestras de productos y ejemplares de abejas nativas sin aguijón (ANSA) para su análisis y caracterización. Gennari GP, Salomon V (eds) INTA,
Estación Experimental Agropecuaria, Famaillá, Tucumán, Argentina.

Isidro A (2006) Las momias: tipología, historia y patología. Revista Española de Antropología Física 26:37-62.

Jara F (1996) La miel y el aguijón. Taxonomía zoológica y etnobiología como elementos en la definición de las nociones de género entre los Andoke (Amazonia colombiana). Journal de la Société des Américanistes 209-258.

Kamienkowski NM, Arenas P (2012) Explotación de himenópteros melíferosentre etnias del Gran Chaco: Una mirada etnobiológica. Mem. XCIMFAUNA 1-8.

Lawless HT, Heymann H (2010) Physiological and Psychological Foundations of Sensory Function. Sensory evaluation of food 19-56.

Maurici B, Pozzo LR, Recanati GB (2018) Descripción Sensorial Cuantitativa de la Miel de Acacia. Revista Tecnología y Ciencia 32:244-249.

Mesa Apícola del Noroeste de Córdoba (2016) Informe Técnico sobre Apicultura de Monte Nativo en el Noroeste de Córdoba. Inédito.

Milojković D, Dražen L, Živoslav T (2015) Modern analyticaltechniques in the assessment of the authenticity of Serbian honey. Arh Hig Rada Toksikol doi: 10.1515/aiht-2015-66-2721.

Montenegro G, Gómez M, Pizarro R, Casaubon G, Peña RC (2008) Implementación de un panel sensorial para mieles chilenas. Ciencia e Investigación Agraria 35:51-58.

Morello J, Rodriguez AF, Silva M (2012) Ecorregión del Chaco Seco. Capítulo 4. In: Morello J, Mateucci SD, Rodriguez AF, Silva ME (eds) Ecorregiones y Complejos ecosistémicos argentinos. Orientación Gráfica Editora, Buenos Aires, Argentina, pp.151-203.

PNUD Argentina (2019) Uso sustentable de biodiversidad (USUBI). Argentina. Programa de las Naciones Unidas para el Desarrollo. http: //www.ar.undp.org Accessed 30 January 2021.

Sancho Valls J, Bota Prieto E, de Castro Martín JJ (1999) Introducción al análisis sensorial de los alimentos. Edicions Universitat, Barcelona, España.

Secretaría de regulación y gestión sanitaria y Secretaría de alimentos y bioeconomía (2019) Official Gazette República Argentina. Resolución Conjunta 17/2019 https://www. boletinoficial.gob.ar/detalleAviso/primera/ 
206764/20190502 Accessed 27 December 2020.

Shack DN (1995) El gusto del catador: determinantes sociales y culturales de las preferencias alimentarias. In: Contreras J (ed). Alimentación y cultura: necesidades, gustos y costumbres Edicions Universitat Barcelona, Barcelona, España, pp.111-129.

Sutton DE (2001) Remembrance of repasts: an anthropology of food and memory. Berg Publishers, New York.

Ulloa JA, Mondragón Cortez PM, Rodríguez Rodríguez R, Reséndiz Vázquez JA, Rosas Ulloa M (2010) La miel de abeja y su importancia. Revista Fuente 4:11-18.

Vit P (2008) Valorización de la miel de abejas sin aguijón (Meliponini). Revista de la Facultad de la Farmacia 50:20-28.

Vit P, Sancho T, Fernandez M, Pascual A, Deliza R (2011) Sensory perception of tropical honeys by
Spanish consumers, using free choice profile. Journal of Api Product and ApiMedical Science doi: 10.3896/IBRA.4.03.4.04.

Vitar B (2000) El impacto de la expulsión de los jesuitas en la dinámica fronteriza del Tucumán. Fundación Histórica Tavera / Colección Proyectos Históricos Tavera, Madrid, España, pp. 1-181.

Zamudio F, Hilgert NI (2017) Cultural, Psychological and Organoleptic Factors Related to the Use of Stingless Bees by Rural Residents of Northern Misiones, Argentina. Chapter 20. In: Vit P, Pedro SRM, Roubik DW (eds) Pot-Pollen in Stingless Bee Melittology Springer, New York, EEUU, pp.283-297.

Received: 22 February 2021

Accepted: 22 April 2021

Published: 8 June 2021 


\section{Additional Files}

Add File 1. Return provided to peasants for the recognition of sensory characteristics of wild honey.

\begin{tabular}{|c|c|c|c|c|}
\hline & Characteristics & Honney & Honey & Honey \\
\hline Color & $\begin{array}{l}\text { Light } \\
\text { medium } \\
\text { Dark }\end{array}$ & & & \\
\hline Tone & $\begin{array}{l}\text { Reddish } \\
\text { Yellowish } \\
\text { Greenishi } \\
\text { Other (describe) }\end{array}$ & & & \\
\hline Odor & $\begin{array}{l}\text { Light } \\
\text { Medium } \\
\text { Intense } \\
\text { What does this smell remind you of? } \\
\text { Describe the odor (i.e. flower, alcohol, wood...) }\end{array}$ & & & \\
\hline Taste & $\begin{array}{l}\text { Sweet } \\
\text { Bitter } \\
\text { Acid } \\
\text { Somewhat salt }\end{array}$ & & & \\
\hline
\end{tabular}

- What honeys belong to Apis mellifera and "mansita"?

A. Apis mellifera: Honey $\mathrm{N}^{\circ}$.

B. Honey of "mansita": Honey $\mathrm{N}^{\circ}$....

- How are the different from "quella" honeys? 
Add File 2. Description of the characteristics of the honey of Plebeia molesta belonging to three environments of the northwest of Córdoba (visual, olfactory and gustatory examination).

\begin{tabular}{|c|c|c|c|c|c|c|c|}
\hline \multirow{2}{*}{ Honeys } & \multicolumn{2}{|c|}{ Visual Examination } & \multicolumn{2}{|c|}{ Olfactory Examination } & \multicolumn{3}{|c|}{ Gustatory Examination } \\
\hline & Physical state & Color & $\begin{array}{l}\text { Intensity } \\
\text { of odor }\end{array}$ & $\begin{array}{l}\text { Description } \\
\text { of odor }\end{array}$ & Taste & Aroma & Persistence \\
\hline M1 & $\begin{array}{l}\text { Very fluid sample, with } \\
\text { few very small crystals } \\
\text { and impurities }\end{array}$ & $\begin{array}{l}\text { Between } \\
\text { amber and } \\
\text { dark amber }\end{array}$ & Moderate & Warm. Fruit & $\begin{array}{l}\text { Sweetness between } \\
\text { weak and moderate. } \\
\text { Acid, salty and bitter: } \\
\text { absence }\end{array}$ & $\begin{array}{l}\text { Warm, fruity, } \\
\text { typical of } \\
\text { Apis mellifera } \\
\text { honey. Very weak } \\
\text { to prune }\end{array}$ & $\begin{array}{l}\text { Almost } \\
\text { imperceptible, } \\
\text { no residual taste }\end{array}$ \\
\hline M2 & $\begin{array}{l}\text { Very fluid sample, with } \\
\text { very few very small } \\
\text { crystals or without } \\
\text { crystals. }\end{array}$ & Dark amber & $\begin{array}{l}\text { Between } \\
\text { week and } \\
\text { moderate }\end{array}$ & $\begin{array}{l}\text { Warm, fruity } \\
\text { (ripe fruit) }\end{array}$ & $\begin{array}{l}\text { Moderate sweetness. } \\
\text { Acid, salty and bitter: } \\
\text { absence }\end{array}$ & Warm & $\begin{array}{l}\text { Low, no residual } \\
\text { taste }\end{array}$ \\
\hline M3 & $\begin{array}{l}\text { Very fluid sample, with } \\
\text { impurities, without } \\
\text { crystals }\end{array}$ & $\begin{array}{l}\text { Between } \\
\text { amber and } \\
\text { dark amber }\end{array}$ & $\begin{array}{l}\text { Between } \\
\text { week and } \\
\text { moderate }\end{array}$ & $\begin{array}{l}\text { Warm, fruity } \\
\text { (processed fruit) }\end{array}$ & $\begin{array}{l}\text { Moderate sweetness } \\
\text { Acid, salty and bitter: } \\
\text { weak acidity }\end{array}$ & $\begin{array}{l}\text { Warm, fruity (ripe } \\
\text { fruit, coffee note) }\end{array}$ & $\begin{array}{l}\text { Medium, no } \\
\text { residual taste }\end{array}$ \\
\hline M4 & $\begin{array}{l}\text { Sample with abundant } \\
\text { amount of crystals, small } \\
\text { and very fluid. It presents } \\
\text { impurities }\end{array}$ & Clear amber & $\begin{array}{l}\text { Between } \\
\text { week and } \\
\text { moderate }\end{array}$ & $\begin{array}{l}\text { Animal (dried } \\
\text { pine mushrooms) }\end{array}$ & $\begin{array}{l}\text { Sweetness between } \\
\text { weak and moderate. } \\
\text { Acid, salty and bitter: } \\
\text { absence }\end{array}$ & $\begin{array}{l}\text { Animal (protein), } \\
\text { warm, "very past } \\
\text { fruit" }\end{array}$ & $\begin{array}{l}\text { Between low and } \\
\text { medium, without } \\
\text { residual taste }\end{array}$ \\
\hline M5 & $\begin{array}{l}\text { Sample with abundant } \\
\text { amount of crystals, very } \\
\text { small and fluid. It presents } \\
\text { impurities }\end{array}$ & Amber & $\begin{array}{l}\text { Medium } \\
\text { intensity }\end{array}$ & Warm, fruit, animal & $\begin{array}{l}\text { Weak sweetness } \\
\text { and Acid }\end{array}$ & $\begin{array}{l}\text { Chemical } \\
\text { (medicinal), } \\
\text { vegetable (moist) }\end{array}$ & $\begin{array}{l}\text { Low, with astringent } \\
\text { trigeminal sensation }\end{array}$ \\
\hline M6 & $\begin{array}{l}\text { Homogeneous sample, } \\
\text { with abundance of very } \\
\text { fine crystals and almost } \\
\text { zero fluidity }\end{array}$ & $\begin{array}{l}\text { Between } \\
\text { amber and } \\
\text { dark amber; } \\
\text { greenish notes }\end{array}$ & Moderate & $\begin{array}{l}\text { Animal (dried } \\
\text { pine mushrooms) }\end{array}$ & $\begin{array}{l}\text { Weak sweetness Acid, } \\
\text { salty and bitter: } \\
\text { weak acidity }\end{array}$ & $\begin{array}{l}\text { Animal (protein), } \\
\text { vegetable, } \\
\text { chemical }\end{array}$ & $\begin{array}{l}\text { Medium, no } \\
\text { residual taste }\end{array}$ \\
\hline M7 & $\begin{array}{l}\text { Barely fluid, with } \\
\text { abundant very fine } \\
\text { crystals }\end{array}$ & Clear amber & Weak & Warm & $\begin{array}{l}\text { Intense sweetness Acid, } \\
\text { salty and bitter: absence }\end{array}$ & $\begin{array}{l}\text { Warm (vanilla, } \\
\text { caramel milk) }\end{array}$ & $\begin{array}{l}\text { In between, without } \\
\text { residual taste }\end{array}$ \\
\hline M8 & $\begin{array}{l}\text { Very fluid sample with } \\
\text { absence of crystals, } \\
\text { presents impurities }\end{array}$ & Dark amber & Moderate & $\begin{array}{l}\text { Fruit (processed } \\
\text { fruit), } \\
\text { warm (burned) }\end{array}$ & $\begin{array}{l}\text { Sweetness between } \\
\text { moderate and intense. } \\
\text { Acid }\end{array}$ & $\begin{array}{l}\text { Fruit (prune), } \\
\text { warm (burned) }\end{array}$ & $\begin{array}{l}\text { Between medium } \\
\text { and long, without } \\
\text { residual taste }\end{array}$ \\
\hline M9 & $\begin{array}{l}\text { Sample with abundant } \\
\text { amount of very fine } \\
\text { crystals and almost z } \\
\text { ero fluidity }\end{array}$ & $\begin{array}{l}\text { Amber very } \\
\text { clear }\end{array}$ & $\begin{array}{l}\text { Between } \\
\text { weak and } \\
\text { moderate }\end{array}$ & $\begin{array}{l}\text { Warm (beewax). } \\
\text { Fruit }\end{array}$ & $\begin{array}{l}\text { Moderate sweetness } \\
\text { Acid, salty and bitter: } \\
\text { absence }\end{array}$ & $\begin{array}{l}\text { Warm, aromatic } \\
\text { (anethole). Oral } \\
\text { touch sensation: } \\
\text { buttery, unctuous }\end{array}$ & $\begin{array}{l}\text { Medium, without } \\
\text { residual taste }\end{array}$ \\
\hline M10 & $\begin{array}{l}\text { Very fluid sample, without } \\
\text { crystals }\end{array}$ & Dark & Weak & $\begin{array}{l}\text { Vegetable (wet). } \\
\text { Fruit (raisin) }\end{array}$ & $\begin{array}{l}\text { Sweetness between } \\
\text { weak and moderate. } \\
\text { Acid, salty and bitter: } \\
\text { absence }\end{array}$ & $\begin{array}{l}\text { Fruit. Vegetable } \\
\text { (wood) }\end{array}$ & $\begin{array}{l}\text { Low, no residual } \\
\text { taste }\end{array}$ \\
\hline
\end{tabular}

